\title{
Survey and Seasonal Distribution of the Rodents in El- Kawther City, Sohag Governorate, Egypt
}

\author{
Abd El-Aleem S S Desoky ${ }^{*}$, Ahmed A Sallam', Wael A M. Radwan ${ }^{2}$ \\ ${ }^{1}$ Plant protection Department, Faculty of Agriculture, Sohag University, Egypt. \\ ${ }^{2}$ postgraduate student.
}

*Corresponding Author: Abd El-Aleem S S Desoky, Plant protection Department, Faculty of Agriculture, Sohag University, Egypt.

\begin{abstract}
The present work was aimed to identify of rodent species at the Experimental Station of the Faculty of Agriculture, Sohag University in El-Kawther city, Sohag Governorate, Egypt during 2014-2016 years. The results were revealed the presence of three species of rats included the white bellied rat, Rattus rattus frugivorus the dominant species from, Rattus rattus alexandrines, the Nile grass rat, Arvicanthis niloticus. These results can be used to develop a future plan to develop an integrated rodent control program based on rodent species present.
\end{abstract}

Keywords Rattus r. frugivorus, Rattus r. alexandrines, Arvicanthis niloticus, Rodent control.

\section{INTRODUCTION}

Rodentia is one of the most important mammalian order which has a great numbers of rodent species with their effect on the environment. Directly, through their destructive feeding habits and indirectly by a stable food items for many predators in the food chains. In Egypt changes in the agro-ecosystem, during the last 40 years, have had a great effect on the distribution and abundance of field rodent population (El-Sherbiny, 1987). Rodents are implicated in many types of damage, including crop and tree damage, structural property and cable damage, disease transmission (Witmer et al., 1998).

In Egypt, the changes of the environment by reclamation the desert and increase the cover plant in this area have been a great effect to the distribution of rodent species (Desoky, 2007 \& Abdel-Gawad, 2010). The present work was aimed to identify of rodent species at study area to be used in the development of a future plan in rodent control programs.

\section{Materials AND Methods}

The present work was carried out in the experimental station of the Faculty of Agriculture, ElKawther city, Sohag University during 2014-2016 years. It is located in newly reclaimed area at the Eastern desert area as arid region $(15 \mathrm{~km}$. East of Sohag Governorate). This area has been planted from along period about (30 years) with isolated patches of vegetables, wheat, Egyptian clover, alfalfa and certain orchards.

20 wire-box traps were baited and distributed twice every week at $6 \mathrm{pm}$ and collected at $7 \mathrm{am}$. The captured rodents were classified and recorded. The Percentage of every species was estimated as a percent from total rodents captured during the year dominant percentage (D \%).

Dominant percentage $=$ Number of rodent species $/$ Total rodents captured $* 100$

Trap index $=$ No. rodent captured $/$ Total traps distributed

\section{RESUlts AND Discussion}

Survey of rodents in El-Kawther city, Sohag Governorate revealed the occurrence of three rodent species in the cultivated area (viz., $R$. $r$. frugivorus, $R$. $r$. alexandrinus and A. niloticus) Table (1) and Figures (1, 2, 3 and 4).

The abundance of captured rodent species in the cultivated area Table (1) was arranged quantitatively in the following descending order. 
- The white bellied rat, $R$. $r$. frugivorus represented by $(82.84 \%)$ in the first year and $(74.63 \%)$ in the second year.

- The percentage of occurrence of the grey bellied rat, $R$. $r$. alexandrinus was (12.43\%) in the first year and $(16.42 \%)$ in the second year.

The Nil grass rat, A. niloticus represented by $(4.73 \%)$ in the first year and $(8.95 \%)$ in the second year.

Data in Table (1) and figures (1, 2, 3 and 4) show that the highest seasonal index of rodents during 2014 / 2015 was recorded in summer (0.23), while the lowest one was found in winter (0.137). On the other hand, in 2015/ 2016 the highest seasonal index of rodents was observed in summer (0.179) and the lowest one in winter (0.087), similar results were obtained by Desoky et al., (2014) finding is in agreement with The results show in the experimental station of the Faculty of Agriculture, El-Kawther city, Sohag University, found that the presence of three species of rats included the Lesser garbia, Gerbillus sp. was recorded (1.08\%) from newly reclaimed area; the Nile grass rat, A. niloticus (4.44\%.) This may be attributed to the availability of food in neighbored field crops and vegetables plantations also, the white bellied rat, $R$. $r$. frugivorus the dominant specie $(94.27 \%$.) This may be due to several factors e.g., intra-specific competition, fecundity increasing and in habitat the ecosystems in which poultry buildings established in the faculty farm the presence of palm trees in the preparation of farm animal production, or poultry farm nearby, this provides shelter and increase in feed stores. The differences in species composition of rodents depending on locality, neighboring, habitat type, inter specific compotation and preferred food.

Identification of rodent species in the study area can be used in the development of a future plan in effective strategy for implementation of rodent management programs in cultivated and newly reclaimed land in Egypt. (El-Sherbiny, 1987\& Desoky et al., 2018)

Table1. Seasonal distribution of rodent species in the cultivated area during $2014-2016$.

\begin{tabular}{|c|c|c|c|c|c|c|c|c|c|c|}
\hline Years & Season & \multicolumn{3}{|c|}{$\boldsymbol{R}$. r. frugivorus } & \multicolumn{3}{c|}{ R. r. alexandrinus } & \multicolumn{3}{c|}{ A. niloticus } \\
\cline { 3 - 11 } & & No. & $\%$ & Trap index & No. & $\%$ & Trap index & No. & $\%$ & Trap index \\
\hline \multirow{4}{*}{$2014 / 2015$} & Winter & 60 & 90.91 & 0.125 & 4 & 6.06 & 0.008 & 2 & 3.03 & 0.004 \\
\cline { 2 - 11 } & Spring & 76 & 84.44 & 0.158 & 12 & 13.34 & 0.025 & 2 & 2.22 & 0.004 \\
\cline { 2 - 11 } & Summer & 88 & 78.05 & 0.183 & 20 & 17.70 & 0.037 & 5 & 4.25 & 0.01 \\
\cline { 2 - 11 } & Autumn & 56 & 81.16 & 0.117 & 6 & 8.70 & 0.013 & 7 & 10.14 & 0.014 \\
\cline { 2 - 10 } & Total & 280 & 82.84 & 0.146 & 42 & 12.43 & 0.021 & 16 & 4.73 & 0.008 \\
\hline \multirow{5}{*}{$2015 / 2016$} & Winter & 36 & 85.72 & 0.075 & 3 & 7.14 & 0.006 & 3 & 7.14 & 0.006 \\
\cline { 2 - 10 } & Spring & 44 & 77.19 & 0.092 & 8 & 14.03 & 0.017 & 5 & 8.78 & 0.01 \\
\cline { 2 - 10 } & Summer & 60 & 69.77 & 0.125 & 18 & 20.93 & 0.038 & 8 & 9.3 & 0.016 \\
\cline { 2 - 10 } & Autumn & 50 & 89.28 & 0.104 & 4 & 7.15 & 0.009 & 2 & 3.57 & 0.004 \\
\cline { 2 - 10 } & Total & 150 & 74.63 & 0.099 & 33 & 16.42 & 0.017 & 18 & 8.95 & 0.009 \\
\hline & G. total & 430 & 78.73 & 0.122 & 75 & 14.43 & 0.019 & 34 & 6.84 & 0.01 \\
\hline
\end{tabular}

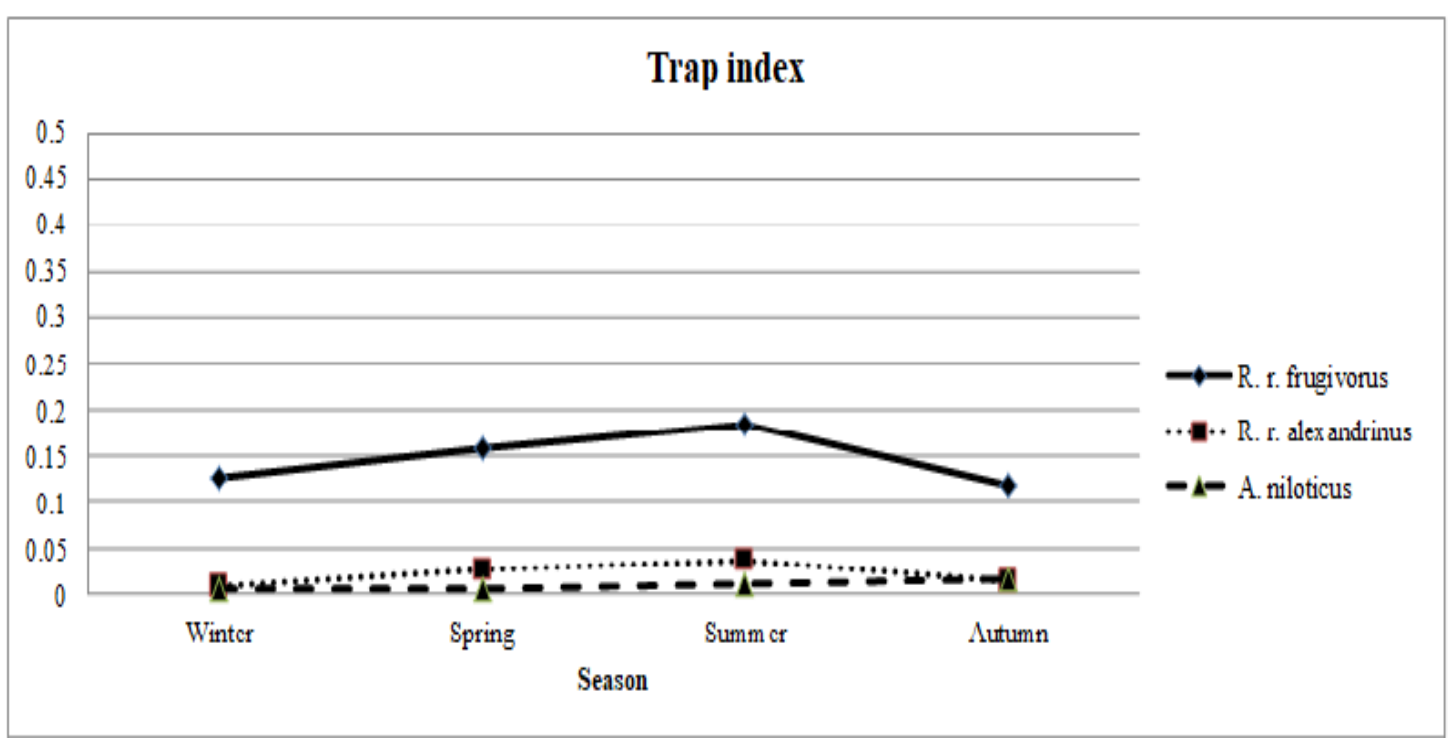

Fig1. Seasonal distribution of rodent species in the cultivated area during 2014/2015. 


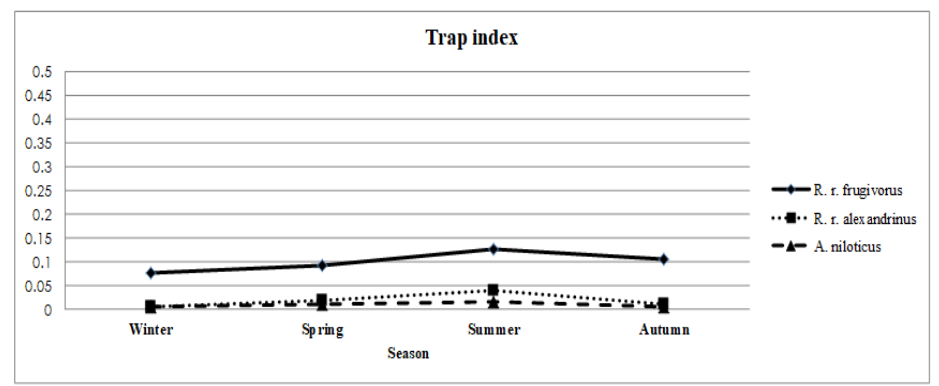

Fig2. Seasonal distribution of rodent species in the cultivated area during 2015/2016.

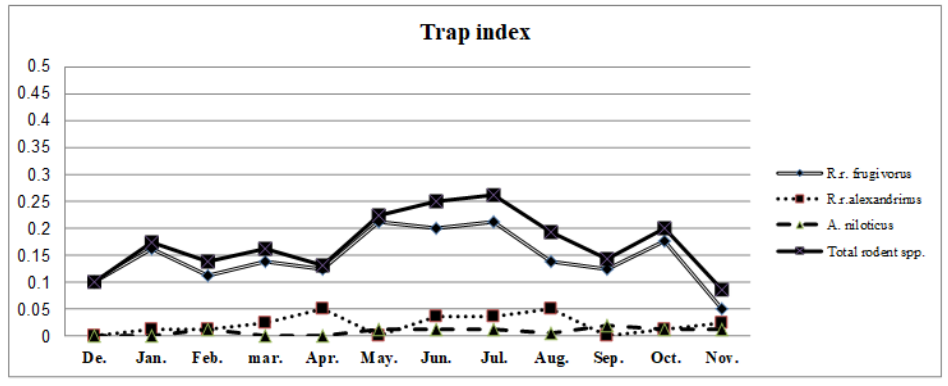

Fig3. Monthly distribution of rodent species in the cultivated area during 2014/2015.

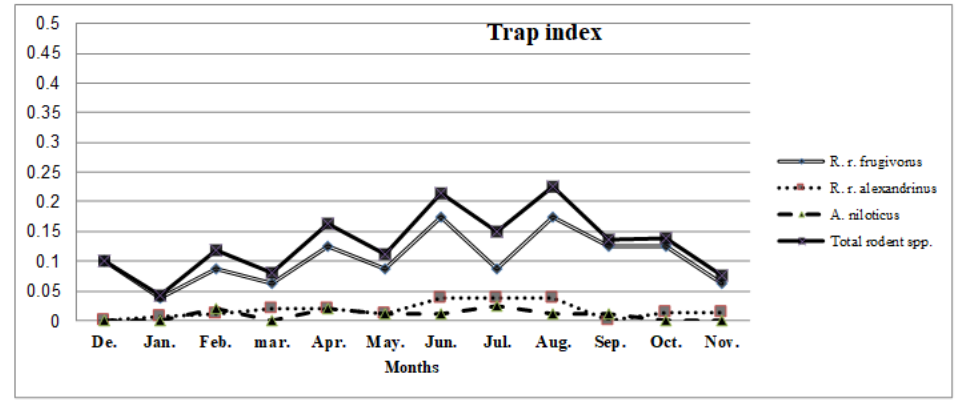

Fig4. Monthly distribution of rodent species in the cultivated area during 2015/2016.

\section{REFERENCES}

[1] Abdel-Gawad K. H. (2010). Rodent species composition in the present compared with past, the 5 Scientific Conferences for Agric. Assiut Univ. Oct. 16-17, 2010 (159-167).

[2] Desoky, A.S. S. (2007). Management strategies for rodents within different ecosystems. M. Sc. Thesis, Fac. Agric. Assiut Univ. 124.

[3] Desoky ASS, Baghdadi SAS, Ahmed HSK (2014). Population density and seasonal distribution of rodent species at sheep farming in El-kawther city, Sohag region, Egypt. J. Plant Prot. and Path., Mansoura Univ., Vol. 5 (10): 903- 907.

[4] Desoky, A.S. S.; A. A Sallam and W. A. M Radwan (2018). Population Density of the White Bellied Rat, Rattus Rattus Frugivorus in El-Kawther City, Sohag Governorate, Egypt. Current Investigations in Agriculture and Current Research 4(2). CIACR.MS.ID.000182.

[5] El-Sherbiny A. H. (1987). Cyclic fluctuation in rodent population: Review of current researches. Egypt wild and not resources Vo: 19 pp 17.

[6] Witmer G, Campbell EW, Boyd F (1998). Rat management for endangered species protection in the U.S. Virgin Islands. Proceedings of the Vertebrate Pest Conference 18:281-286.

Citation: Abd El-Aleem S S Desoky., et.al., " Survey and Seasonal Distribution of The rodents in El-Kawther City, Sohag Governorate, Egypt ", International Journal of Research Studies in Zoology, vol. 5, no. 1, p. 11-13, 2019. DOI: http://dx.doi.org/10.20431/2454-941X.0501002

Copyright: (C) 2019 Authors. This is an open-access article distributed under the terms of the Creative Commons Attribution License, which permits unrestricted use, distribution, and reproduction in any medium, provided the original author and source are credited. 